\title{
Research of Technique and Technology for Processing Cocoons Silkworm
}

\author{
Safarov Jasur*, Sultanova Shaxnoza, Dadaev Gani, Zulpanov Shovqiddin, Erkinov Dilmurod \\ Tashkent State Technical University, Republic of Uzbekistan
}

Submission: March 12,2018; Published: April 23, 2018

"Corresponding author: Safarov Jasur, Tashkent State Technical University, Tashkent100095, Republic of Uzbekistan, Email: jasursafarov@yahoo.com

\section{Abstract}

The proposed development of technique and technology for high-quality processing of silkworm cocoons using low temperature with the help of infrared radiation, elastic waves and convective heat supply. With the use of this technique and technology, the process of processing acceleration is ensured, as well as the quality of the resulting silk.

Keywords: Cocoons of the silkworm; Elastic waves; Infrared radiation

\section{Introduction}

Natural silk is in great demand in many countries. On consumer properties it is higher than other textile fibers. Great strength, high elasticity, hygroscopicity, beauty of fabrics, indispensability of silk fiber in some technical manufactures, makes silk unique. Silkworming around the world to date remains the most weakly mechanized branch of agriculture.

One of the important ways to increase the agricultural sector's importance is to improve the technology of production of silkworm grenkins and cocoons based on the integrated mechanization of the main processes in silkworm breeding.

In Japan (also one of the leading countries of sericulture), there is now a sharp decline in the production of cocoons and as a result, raw silk. The reason is the same - the labor intensity of production, the care of workers in other more popular industries. Although the processes are somewhat better mechanized than in other countries. But this is basically a small handicraft mechanization and it is also far from enough. The great demand for natural silk led to Japan importing cocoons and raw silk from Korea, China, partly from the CIS, negotiations are underway to establish joint ventures [1].

The solution of scientific and practical issues to increase the production of cocoon raw materials and improve its quality on the basis of improving technological processes are devoted to a number of foreign and domestic works of scientists and practitioners.

\section{Materials and Methods}

Works aimed at improving technique and technology for processing cocoons of silkworm processes through the widespread introduction of integrated mechanization, will reduce labor costs and improve product quality. A more attractive mechanized labor will reduce the turnover of personnel and will give impetus to a more effective use of the achievements of scientists in silkworm breeding. Therefore, these studies and developments are of theoretical and practical interest.

Drying is the thermal process of dehydration of products by evaporation of moisture and evacuation of formed vapors. At the same time, heat transfer and diffusion migration of moisture take place in the material. The drying process is used in many industries. The proposed technology of drying silkworm cocoons using low temperature using infrared (IR) radiation, elastic waves, vibration and convective heat supply is one of the most innovative and more suitable methods of drying. The development of such equipment is quite a promising direction. Technological features of this process make it possible to achieve effective carrots and high-quality drying of cocoons of silkworm. In addition, the task is to obtain new qualities in the finished product. To achieve these goals, it is necessary to use appropriate efficient energy-saving equipment with the use of a low temperature at which the raw materials for the textile industry that are produced retain their quality and appearance. 
The process of recycling silkworm cocoons is characterized by a number of parameters: the quality and quantity of raw materials and finished product, the temperature and relative humidity of the medium, the residence time of the product in the equipment [2-5].

The advantages of excitation of waves in the elastic system of cocoons give rise to a low resonant frequency, suitable for practical purposes, i.e. It is possible to use high-frequency and low-frequency elastic waves, $\left(f_{\text {resonant }} \leq 30 \mathrm{kHz}\right)$.

Oscillations of elastic waves inside the production create conditions for improving mass-heat transfer under conditions of the existence of a pressure gradient and temperature. The vibrations of elastic waves increase the rate of formation of these waves by means of capillary moisture transfer. The use of these vibrations in dehydration systems enhances the effects of moisture evaporation and cocoon carrot.

The use of elastic wave oscillations in carrots and drying of silkworm products in the frequency range $26-35 \mathrm{kHz}$ showed the acceleration of the process. Working temperature in the process of carrots and drying cocoons of silkworm $70-80{ }^{\circ} \mathrm{C}$.

One of the possible options for creating vibratory movements for carrots and drying products is the development of the vibration mechanism of all equipment, in particular the cabinet, together with the products. To solve this problem, it is necessary to create a vibration-mechanism device that creates mechanical low-frequency oscillations with respect to the fixed platform.

To create low-frequency $(\tau<100 \mathrm{~Hz})$ mechanical oscillations for carrots and drying of raw materials in a stationary installation, various mechanisms can be proposed that create translational or rotational motions. The main purpose of these mechanisms should be the creation of vertical vibrations of horizontally located working shelves.

Infrared radiation is a kind of electromagnetic radiation occupying a range of 0.77 to $340 \mathrm{mcm}$ in the spectrum of electromagnetic waves. In this case, the range from 0.77 to $15 \mathrm{mcm}$ is considered short-wave, from 15 to $100 \mathrm{mcm}$ mediumwave, and from 100 to 340 long-wave. The short-wave part of the spectrum adjoins the visible light, and the long-wavelength part merges with the region of ultrashort radio waves. Therefore, infrared radiation has both the properties of visible light (propagates rectilinearly, is reflected, refracted, like visible light), and the properties of radio waves (it can pass through some materials that are opaque to visible radiation).

At the heart of IR-processing technology lies the ability of water molecules to absorb a certain spectrum of infrared radiation. In this case, the product organics with a certain degree of reliability can be considered transparent for infrared rays.
Thus, the energy that is converted from electricity without losses is completely transferred to the water of the product, heating it and causing it to evaporate.

As heat generators of IR radiation for industrial drying plants of raw materials in our country and abroad heaters of different types and designs are used. They differ in the wavelength of the maximum radiation, depending on the temperature and methods of heating (electric, gas) and the elements of resistance (metal, ceramic, silicate). The transformation of radiant energy into thermal energy is caused by the thermoradiation spectral properties of the product, i.e. its transmissive, reflective and absorbing capacity. The energy of IR radiation is converted into heat only if it is absorbed by the irradiated substance. For different materials, the degree of absorption and the penetration depth of infrared rays are different, since the materials are selectively related to the wavelength of the incident radiation. The wavelength, in turn, depends on the temperature of the IR generator.

Thus, the spectral optical properties of the product and the spectral characteristics of the heaters are interrelated and of paramount importance. With a valid choice of the type of radiator and the irradiation regime, infrared radiation penetrates into the product, which intensifies heat and mass transfer processes.

\section{Conclusion}

The proposed development of technique and technology for carrots and drying cocoons of the silkworm - works with a low temperature, infrared, vibration equipment, using elastic waves and convective heat supply. With the use of this technique and technology, the process of recycling acceleration is ensured, as well as the quality of the resulting silk.

\section{References}

1. Burlakov VS (2005) Increase the efficiency of silkworm breeding on the basis of new technologies using the developed technical means. Diss Doct agricultural sciences Belgorod p. 275.

2. Norkulova KT, Umarov VF, Safarov JE (2009) Use of the vibrating mechanism in drying cabinets. Proceedings of KSTU Bishkek 17: $135-136$.

3. Safarov JE, Sultanova Sh A, Dadaev GT (2017) Mathematical modeling of the linear stationary process of drying with accuracy of evaporation and temperature relation on the surface of the layer in infrared heating. Agricultural Research \& Technology: Open Access Journal 9(5): 001-003.

4. Safarov JE, Sultanova Sh A, Dadaev GT (2018) Study of the processing of the pupa of the cocoons of the silkworm. International scientific-practical conference, Modeling and analysis of complex technical and technological systems, Samara.

5. Safarov JE (2010) Nonlinear processes in the propagation of heat in a layer of a dehydrated object. Theses of the reports of the youth scientific conference, Lomonosov-2010 Tashkent, p. 43-45. 
This work is licensed under Creative Commons Attribution 4.0 License DOI: 10.19080/ARTOAJ.2018.15.555960
Your next submission with Juniper Publishers will reach you the below assets

- Quality Editorial service

- Swift Peer Review

- Reprints availability

- E-prints Service

- Manuscript Podcast for convenient understanding

- Global attainment for your research

- Manuscript accessibility in different formats ( Pdf, E-pub, Full Text, Audio)

- Unceasing customer service

Track the below URL for one-step submission https://juniperpublishers.com/online-submission.php 